The past twenty-five years have proved the contrary. Although some very elegant experiments have been performed and a great number of calculations have been carried out, the details, both theoretical and experimental, still prove to be very elusive.

\section{Diamond in a kimberlite xenolith}

from G. Malcolm Brown

Mosr of the world's diamonds occur as sparsely distributed crystals in the rare, ultramafic potassic rock called kimberlite. The rock is found in pipe-like bodies that reach the present Earth surface, as for example in the major diamond localities of South Africa and Siberia. There is no doubt that the kimberlite material was injected into the crust from deep levels of the Earth, aided in many cases by the explosive forces of a high gas content. The kimberlite matrix has apparently crystallised from a liquid magma, and the fascinating array of rock fragments (xenoliths) embedded in the matrix bear testimony to the source of the magma. These xenoliths are mainly garnet lherzolites, rocks consisting chiefly of garnet, olivine, clinopyroxene and orthopyroxene crystals. Such ultramafic rocks are now widely accepted as being most closely representative of the composition of the Earth's upper mantle. Hence the intrusion of kimberlite has resulted in the transport, to nearsurface environments, of parts of the Earth that are otherwise invisible except by indirect geophysical measurements.

Diamonds are not a geologist's best friend. Most minerals occur in a textural association with other minerals such that constraints can be placed on the physico-chemical properties of the whole rock assemblage, and much information can thus be gained about the processes involved in their origin. In contrast, most diamonds occur within the heterogeneous, often fragmentary matrix of the kimberlite pipes and the critical information on temperatures and pressures (and thus depths) of origin can only be inferred from studies on the associated, but generally diamond-free fragments of ultramafic upper mantle (lherzolitic) rock. Another complicating factor is that whereas lherzolite xenoliths occur in many volcanic lavas generated from the upper mantle, they are diamond-free. Hence the genesis of diamond has seemed to be associated specifically with the kimberlite matrix of the diamond pipes, rather than with upper mantle xenoliths as a whole.

Dawson and Smith (Nature, 254, $580-581$; 1975) have therefore made an important recent discovery. They describe the finding of a small diamond crystal $(0.8 \times 1.4 \mathrm{~mm})$ in a thin section preparation of a mica-bearing garnet lherzolite xenolith from a kimberlite pipe (diatreme) in Lesotho. C. F. Davidson once wrote that "the richest kimberlites ... carry one part diamond in $10^{7}$ of rock, and the average is one in $10^{10}$ or less. So the chances of finding a diamond in a thin section are somewhat around the cube of the probability of finding the needle in the haystack" (in Ultramafic and Related Rocks, edit. by Wyllie, 302; Wiley, 1967). Small wonder, therefore, that diamonds are rarely detected other than by the crushing and sorting of huge volumes of kimberlite rocks. Dawson and Smith refer to the few previously recorded occurrences of diamond in eclogite and garnet serpentinite xenoliths from kimberlites, but those xenoliths are of slightly lesser relevance to an upper mantle source material.

The discovery of diamond in the lherzolite permits mineralogists to use the lherzolite minerals in order to estimate the pressure $(P)$ and temperature $(T)$ of formation of the included diamond crystal. In fact, studies of this type have been pursued vigorously since 1973 , stemming especially from original work by Boyd and coworkers on the pyroxene mineralogy. Unfortunately, despite a number of sophisticated studies on the phase equilibria and related thermodynamic calculations, the topic is still plagued by doubts as to the dependability of certain data used in the geothermometry and geobarometry estimates. Each new study adds further refinements, though the basic concepts are not questioned, and it is premature for readers to assume that the $P-T$ values given by Dawson and Smith are better than a very broad estimate.

They give valuable mineral analyses and conclude that the assemblage equilibrated at $1.050{ }^{\circ} \mathrm{C}$, at a pressure of about 4.6 to $5.2 \mathrm{kPa}$ (that is, about $150 \mathrm{~km}$ depth). There are, however, several other lines of evidence that need to be considered. Graphite, the other form of carbon in igneous rocks, occurs in some garnet lherzolite xenoliths in kimberlites, as they mention, so the $P-T$ curve for the graphite-diamond transition is relevant in the sense that proximity to this phase boundary is likely. Also, studies of mineral inclusions in diamonds have yielded important data for $P-T$ estimates.

A method of estimating $P-T$ conditions that is more rigorous than analogy with simple synthetic systems is more than overdue. Such an approach, using thermodynamic parameters to formulate a geothermometer based on the iron-magnesium exchange reaction between olivine and calcium- rich clinopyroxene, has recently been developed by Powell and Powell (Contr. Min. Petrol., 48, 249-263; 1974). They examine $P-T$ conditions for inclusions in diamond and for ultrabasic xenoliths in kimberlites, and the related studies are cited. Where the $P-T$ lines are drawn for those assemblages, they intersect the graphite-diamond transition line at about $1,250^{\circ} \mathrm{C}$ and 4.5 $\mathrm{kPa}$. Thus the pressures inferred by Dawson and Smith are corroborated, but the temperature discrepancy is $200^{\circ} \mathrm{C}$. In fact, plotting of the Dawson and Smith data (at $1,050^{\circ} \mathrm{C}$ ) on the Powell and Powell diagram would suggest equilibration improbably close to the wet pyrolite solidus.

Reference to other methods of estimating $P-T$ conditions, which may or may not be proven better, is made merely to stress the need for caution in accepting specific values at this stage in a rapidly developing science. The major contribution by Dawson and Smith remains an exciting one. They raise other interesting points regarding the stability of phlogopite mica, diamond growth habits, and the possible genesis of graphite by breakdown of diamond. Above all, however, they remind us that the processes of generation of diamond are interwoven with the processes of upper mantle dynamics and magma generation at around $150 \mathrm{~km}$ depth in the Earth.

\section{A probe probed}

from E. G. Richards

To investigate the structure of DNA you need a probe that will interact with the macromolecule. Electromagnetic radiation has long been a favourite but various chemical reagents are strong contenders. Of these, the simplest is the proton and the next most simple is possibly formaldehyde but in order to interpret the interactions you observe you need to know in detail what is going on. This thas hitherto been more than a little obscure in the case of formaldehyde, a matter which has now been put to rights by two elegant and exhaustive papers by McGhee and von Hippel (Biochemistry, 14, 1281 and 1297; 1975).

To begin with, formaldehyde can react with both the exocyclic amino groups of $\mathrm{A}, \mathrm{C}$ and $\mathrm{G}$ residues and the endocyclic imino groups of $\mathrm{T}$ and $\mathrm{G}$ (and U and I). In each case the result is the substitution of a hydrogen atom by a methylol $\left(-\mathrm{CH}_{2} \mathrm{OH}\right)$ group. In the case of the reaction with the amino group, a monoadduct or a diadduct may be formed acconding to whether just one or both hydrogens are substituted and it would seem that the ghost of the Schiff base has been laid. A further wrinkle in the exocyclic re- 